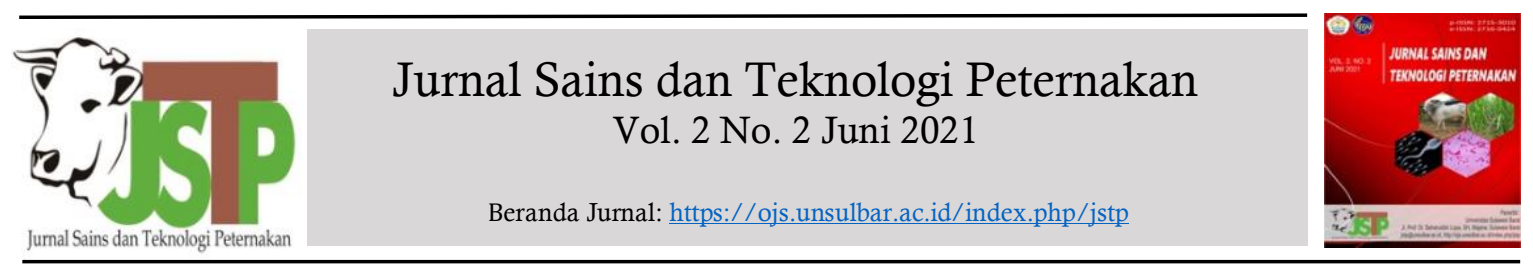

\title{
Perancangan Primer Gen IktB pada Fusobacterium necrophorum untuk Analisis PCR
}

(Primer Design of IktB Gene on Fusobacterium necrophorum for PCR Assay)

\author{
Rian Ka Praja ${ }^{1^{*}}$, Reny Rosalina ${ }^{2}$
}

${ }^{1}$ Ilmu Biomedik, Fakultas Kedokteran, Universitas Udayana, Jl. Sudirman, Sanglah, Denpasar, Bali, Indonesia 80234.

${ }^{2}$ Departemen Kimia, Fakultas Matematika dan Ilmu Pengetahuan Alam, Institut Teknologi Bandung, Jl. Ganesa No. 10, Bandung, Jawa Barat, Indonesia 40132.

\begin{tabular}{l}
\hline A R T I C L E I N F O \\
\hline Received: 18 Februari 2021 \\
Accepted: 17 Mei 2021 \\
*Corresponding author \\
riankapraja@gmail.com \\
\\
Keywords: \\
Fusobacterium necrophorum \\
In silico \\
Leukotoxin B \\
Necrobasillosis \\
Primer \\
\hline
\end{tabular}

\section{Kata Kunci:}

Fusobacterium necrophorum

In silico

Leukotoksin B

Nekrobasillosis

Primer

\section{A B S T R A C T}

Fusobacterium necrophorum is a pathogen causing disease in animals, especially cattle, goats, and sheep. F. necrophorum infection can result in a variety of necrotic conditions (necrobacillosis). This study aimed to design a pair of primers for detecting the leukotoxin $B$ (lktB) gene expressed by $F$. necrophorum as diagnostic support. The lktB gene sequence was obtained from GenBank NCBI with accession number AF312861.3:685-2337. Furthermore, the sequence was used as a template for in silico primer design using Primer-BLAST. Primer candidates successfully designed were then analyzed for their secondary structure using NetPrimer. The results showed that forward primer set 6 (5'-TCGGATGCTGGAATGCTACTT-3') and reverse primer set 6 (5'-GGGCTCCCAAATCCTTACGA-3') were a favorable primer set with a product size of $228 \mathrm{bp}$. However, laboratory experiments need to be carried out to determine the optimal conditions for this primer set.

A B S T R A K

Fusobacterium necrophorum merupakan patogen yang dapat menyebabkan penyakit pada berbagai hewan khususnya sapi, kambing, dan domba. Infeksi $F$. necrophorum dapat mengakibatkan berbagai kondisi nekrotik (nekrobasilosis). Penelitian ini bertujuan untuk mendesain primer untuk mendeteksi gen leukotoxin $B($ lktB) yang diekspresikan oleh $F$. necrophorum sebagai penunjang diagnosis. Urutan gen $l k t B$ diperoleh dari GenBank NCBI dengan nomor akses AF312861.3:685-2337. Selanjutnya urutan gen tersebut digunakan sebagai cetakan untuk desain primer secara in silico menggunakan Primer-BLAST. Kandidat primer yang telah berhasil didesain kemudian dianalisis struktur sekundernya menggunakan NetPrimer. Hasil penelitian menunjukkan bahwa primer forward 6 (5'-TCGGATGCTGGAATGCTACTT-3') dan primer reverse 6 (5'GGGCTCCCAAATCCTTACGA-3') memenuhi syarat sebagai primer yang baik dengan amplikon berukuran 228 bp. Eksperimen lebih lanjut di laboratorium perlu dilakukan untuk menentukan kondisi optimal dari pasangan primer ini. 


\section{Pendahuluan}

Fusobacterium necrophorum menyebabkan berbagai kondisi nekrotik (nekrobasilosis), baik infeksi spesifik maupun non-spesifik, pada berbagai hewan. Laporan berbagai kasus menunjukkan bahwa abses hati dan penyakit kaki busuk (foot rot) menjadi perhatian penting bagi industri peternakan (Clifton, Giebel, Liu, Purdy, \& Green, 2019; Saleh et al., 2019; Veloso \& Drouillard, 2020). Mekanisme patogenesis infeksi $F$. necrophorum sangat kompleks. Beberapa toksin atau produk yang disekresikan, seperti leukotoxin, endotoxin, hemolysin, hemagglutinin, protease, dan adhesin telah dilaporkan sebagai faktor virulensi yang diekspresikan oleh $F$. necrophorum (Van Metre, 2017).

Leukotoxin merupakan faktor virulensi mayor yang diproduksi oleh $F$. necrophorum. (Pillai, Amachawadi, Baca, Narayanan, \& Nagaraja, 2021). Urutan lengkap nukleotida dari leukotoxin $F$. necrophorum telah berhasil diidentifikasi. Protein leukotoxin F. necrophorum disandi oleh operon trisistronik yang terdiri dari lktB, $A$, dan $C$ (Umana et al., 2019). Protein $l k t A$ telah diidentifikasi mampu menginduksi apoptosis dan nekrosis pada leukosit sapi (Pillai et al., 2021; Tadepalli, Stewart, Nagaraja, \& Narayanan, 2008). Secara struktural, protein $l k t B$ memiliki domain POTRA_2 (polypeptide transport-associated domain) pada residu asam amino 85-160 dan domain Sh1B pada residu asam amino $172-549$. Kedua domain ini terkait dengan type $\mathrm{Vb}$ secretion system yang memiliki fungsi biologis yang berhubungan dengan sistem transport dan sekresi toksin $l k t A$. Sementara itu, fungsi biologis $l k t C$ masih belum diidentifikasi lebih lanjut (Tadepalli et al., 2008).

Terobosan dalam bidang biologi molekuler telah membawa kemajuan pesat di bidang veteriner. Teknik biologi molekuler seperti polymerase chain reaction (PCR) dapat digunakan untuk mendeteksi keberadaan gen yang berperan sebagai faktor virulensi pada suatu patogen. PCR yang bertujuan untuk mengamplifikasi DNA terdiri dari tiga tahap. Tahap awal dari proses amplifikasi adalah denaturasi untai DNA, kemudian pasangan primer menempel pada fragmen DNA target (annealing), dan tahap terakhir adalah proses perpanjangan urutan DNA (Kadri, 2020).

Primer oligonukleotida merupakan komponen yang sangat penting dalam teknik PCR. Primer yang baik adalah primer yang memiliki sifat spesifik yang diharapkan mampu mengamplifikasi area spesifik dalam genom (Praja, 2021; Sint, Raso, \& Traugott, 2012). Seiring dengan perkembangan basis data
GenBank NCBI, desain primer kini dapat dilakukan dengan pendekatan in silico. Studi in silico adalah studi yang dilakukan menggunakan pendekatan komputasi. Secara umum, studi in silico memanfaatkan basis data yang tersedia untuk dijadikan objek penelitian (Saraswati, Seprianto, \& Wahyuni, 2019). Penelitian ini bertujuan untuk merancang dan menganalisis primer oligonukleotida secara in silico untuk mengamplifikasi gen $l k t B F$. necrophorum.

\section{Materi dan Metode}

\subsection{Pencarian Urutan Gen lktB F. necrophorum}

Urutan gen $l k t B F$. necrophorum diperoleh menggunakan menu pencarian "nucleotide" yang disediakan oleh GenBank NCBI (https://www.ncbi.nlm.nih.gov/genbank/).

Urutan gen lktB $F$. necrophorum yang digunakan pada penelitian ini adalah urutan dengan nomor akses AF312861.3:685-2337. Urutan gen $l k t B$ yang diperoleh kemudian disimpan ke dalam bentuk format FASTA untuk selanjutnya digunakan dalam proses desain primer secara in silico.

\subsection{Desain Primer secara In Silico}

Kandidat pasangan primer yang akan digunakan untuk mengamplifikasi gen $l k t B$ didesain menggunakan Primer-BLAST tool (https://www.ncbi.nlm.nih.gov/tools/primerblast/) dengan parameter tertentu (Tabel 1). Urutan gen dalam format FASTA yang berisi urutan gen $l k t B$ diunggah ke Primer-BLAST dan kemudian akan diperoleh beberapa pasangan primer yang memiliki potensi untuk mengamplifikasi gen $l k t B$.

Tabel 1. Parameter yang digunakan pada PrimerBLAST

\begin{tabular}{ll}
\hline Parameter & Pengaturan \\
\hline PCR product size & Min: 70 \\
& Max: 1000 \\
\hline \# of primers to return & 10 \\
\hline Primer melting temperatures & Min: 57.0 \\
$\left(T_{m}\right)$ & Opt: 60.0 \\
& Max: 63.0 \\
& Max Tm difference: 3 \\
\hline
\end{tabular}

\subsection{Analisis Struktur Sekunder}

Seluruh pasangan primer yang telah didesain harus dianalisis struktur sekundernya untuk menemukan kandidat pasangan primer yang terbaik. Analisis struktur sekunder yang terdiri dari self dimer, hairpin, repeat, dan run dilakukan menggunakan aplikasi NetPrimer yang dapat diakses melalui 
http://www.premierbiosoft.com/NetPrimer/A nalyzePrimer.jsp.

\subsection{Uji Similaritas}

Uji similaritas dilakukan untuk menguji apakah primer yang telah didesain mampu mengamplifikasi gen $l k t B$ secara spesifik. Uji ini dilakukan menggunakan fitur Nucleotide BLAST yang tersedia secara online pada https://blast.ncbi.nlm.nih.gov/Blast.cgi. Urutan primer nukleotida yang telah berhasil dirancang selanjutnya diunggah dan akan diperoleh nilai persentase kesamaan (similarity) dengan urutan gen yang terdapat pada basis data GenBank NCBI.

\section{Hasil dan Pembahasan}

Studi in silico ini berfokus pada perancangan primer oligonukleotida menggunakan aplikasi Primer-BLAST untuk amplifikasi gen lktB. Urutan gen lkt $F$. necrophorum yang terdiri dari gen $l k t B, A$, dan $C$ diperoleh melalui GenBank NCBI dengan nomor akses AF312861.3. Penelitian ini secara spesifik hanya menggunakan daerah gen $l k t B$ (daerah 685-2337) dengan urutan seperti pada Gambar 1.
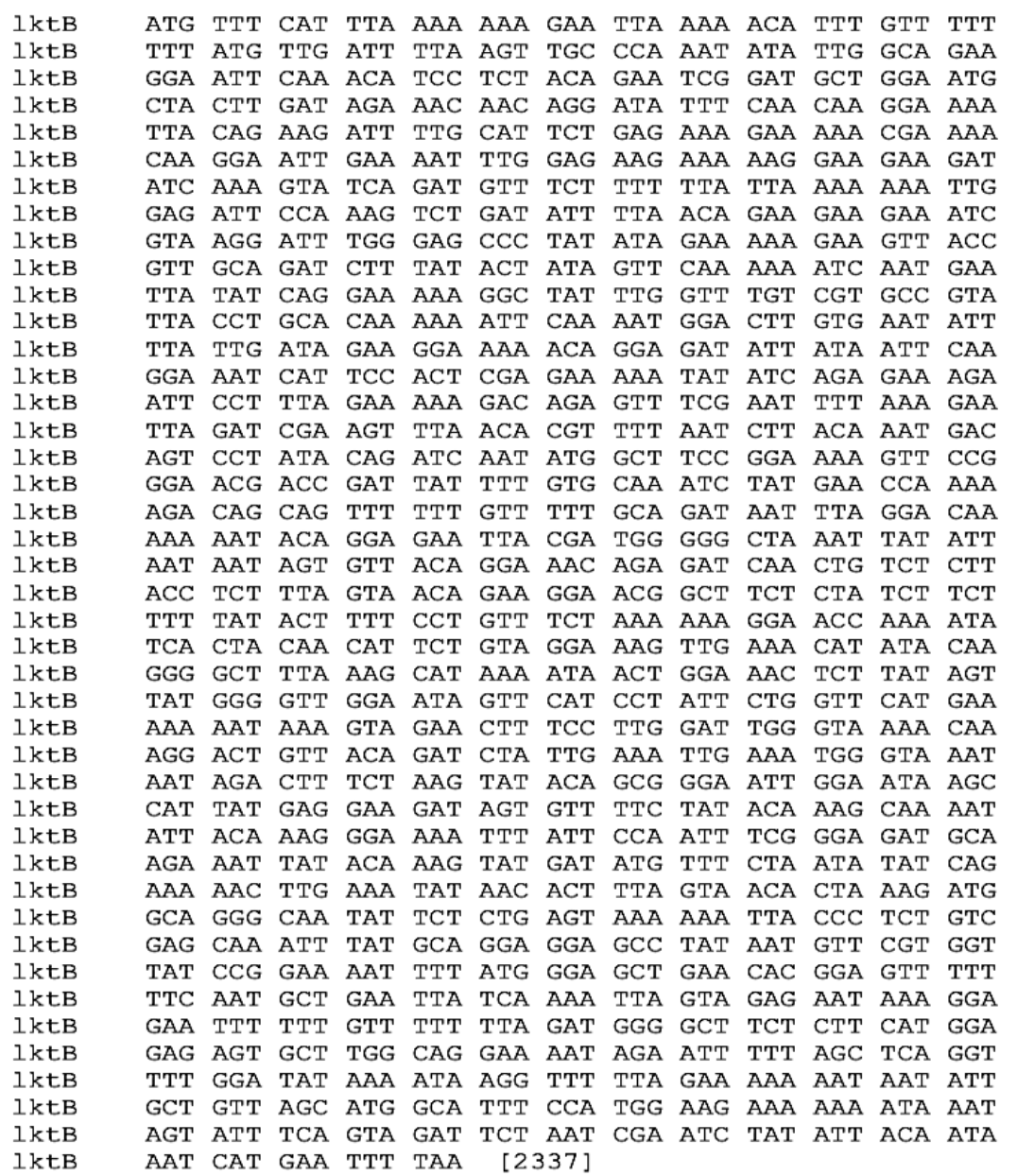

[723]

[762]

[ 801]

[ 840]

[ 879]

[ 918]

[ 957]

[996]

[1 035 ]

[1074]

[1113]

[1152]

[1191]

[1230]

[1269]

[1308]

[1374]

[1386]

[1425]

[1464]

[1503]

[1542]

[1581]

[1620]

[1659]

[1698]

[1737]

[ 1776 ]

[1815]

[1854]

[1893]

[1932]

[1971]

[2010]

[2049]

[2088]

[2127]

[2166]

[2205]

[2244]

[2283]

[2322]

Gambar 1. Urutan nukleotida gen $l k t B F$. necrophorum. Gen $l k t B$ memiliki susunan nukleotida dengan panjang 1653 bp yang diperoleh dari GenBank NCBI dengan nomor akses AF312861.3:685-2337.

Perangkat lunak Primer-BLAST menghasilkan sepuluh pasang kandidat primer untuk mengamplifikasi gen $l k t B F$. necrophorum di daerah 685-2337 dari urutan DNA lengkap gen penyandi leukotoxin (Gambar 1). Sepuluh pasang primer yang dirancang oleh Primer-BLAST menunjukkan keragaman terkait ukuran produk
PCR, panjang primer, $T m$, dan persentase GC (Tabel 2). Produk terpendek dan terpanjang dihasilkan oleh pasangan primer 9 dan 3 dengan masing-masing 105 dan 751 bp (Gambar 2). Selanjutnya suhu leleh (Tm) dari masing-masing pasangan primer memiliki perbedaan tidak 
melebihi $5{ }^{\circ} \mathrm{C}$ dengan temperatur berkisar 59,23 $60,89^{\circ} \mathrm{C}$.

Urutan primer oligonukleotida yang diperoleh dari Primer-BLAST kemudian dianalisis lebih lanjut untuk mengidentifikasi primer yang paling efisien. Analisis untuk mengidentifikasi self dimer, hairpin, repeat, dan run dilakukan menggunakan NetPrimer. Semua primer yang dianalisis menunjukkan hasil yang bervariasi dalam hal self dimer, hairpin, repeat dan run. Selain itu, NetPrimer juga memberikan penilaian (rating) terkait kualitas primer. Kisaran rating primer yang telah didesain berkisar 62 sampai 100 dan pasangan primer 6 adalah pasangan primer dengan rating tertinggi di antara semua primer yang didesain menggunakan Primer-BLAST (Tabel 3).

Tabel 2. Kandidat primer untuk mengamplifikasi gen $l k t B$ yang didesain menggunakan Primer-

\begin{tabular}{|c|c|c|c|c|}
\hline \multicolumn{5}{|l|}{ BLAST } \\
\hline Urutan $\left(5^{\prime}->3^{\prime}\right)$ & Panjang & $\mathrm{Tm}$ & GC \% & Panjang Produk (bp) \\
\hline Pasangan Primer 1 & 20 & 59,45 & 55,00 & \multirow{3}{*}{126} \\
\hline F: CGTAAGGATTTGGGAGCCCT & 20 & 60,46 & 55,00 & \\
\hline R: GCAGGTAATACGGCACGACA & & & & \\
\hline Pasangan Primer 2 & 20 & 59,23 & 55,00 & \multirow[t]{2}{*}{747} \\
\hline F: GGAGAATTACGATGGGGGCT & 20 & 59,75 & 55,00 & \\
\hline R: CTGCCAAGCACTCTCTCCAT & & & & \multirow{3}{*}{751} \\
\hline Pasangan Primer 3 & 20 & 59,23 & 55,00 & \\
\hline F: AGGAGAATTACGATGGGGGC & 20 & 59,68 & 55,00 & \\
\hline R: TTCCTGCCAAGCACTCTCTC & & & & \\
\hline Pasangan Primer 4 & 21 & 59,86 & 47,62 & \multirow[t]{2}{*}{341} \\
\hline F: GAATCGGATGCTGGAATGCT & 20 & 60,46 & 55,00 & \\
\hline R: GTGCAGGTAATACGGCACGA & & & & \multirow{3}{*}{110} \\
\hline Pasangan Primer 5 & 20 & 58,89 & 50,00 & \\
\hline F: TCCGGGAACGACCGATTATT & 20 & 59,23 & 55,00 & \\
\hline R: GCCCCCATCGTAATTCTCCT & & & & \multirow{3}{*}{228} \\
\hline Pasangan Primer 6 & 21 & 59,51 & 47,62 & \\
\hline F: TCGGATGCTGGAATGCTACTT & 20 & 59,46 & 55,00 & \\
\hline R: GGGCTCCCAAATCCTTACGA & & & & \multirow{3}{*}{228} \\
\hline Pasangan Primer 7 & 21 & 59,40 & 52,38 & \\
\hline F: CGGATGCTGGAATGCTACTTG & 20 & 59,45 & 55,00 & \\
\hline R: AGGGCTCCCAAATCCTTACG & & & & \multirow{3}{*}{250} \\
\hline Pasangan Primer 8 & 21 & 59,61 & 52,38 & \\
\hline F: GGTTTGTCGTGCCGTATTACC & 20 & 60,89 & 55,00 & \\
\hline R: CGGAACTTTTCCGGAAGCCA & & & & \multirow{4}{*}{105} \\
\hline Pasangan Primer 9 & 20 & 59,75 & 55,00 & \\
\hline F: TCATGGAGAGAGTGCTTGGC & 22 & 60,09 & 45,45 & \\
\hline R: GAAATGCCATGCTAACAGCAA & & & & \\
\hline Pasangan Primer 10 & 21 & 59,79 & 52,38 & \multirow[t]{2}{*}{124} \\
\hline F: TTATGGGAGCTGAACACGGAG & 21 & 59,86 & 47,62 & \\
\hline
\end{tabular}

R: TTTTCCTGCCAAGCACTCTCT

Keterangan: $\mathrm{F}=$ primer forward $\mathrm{R}=$ primer reverse, $\mathrm{Tm}=$ suhu leleh, $\mathrm{GC} \%=$ persentase basa $\mathrm{GC}$

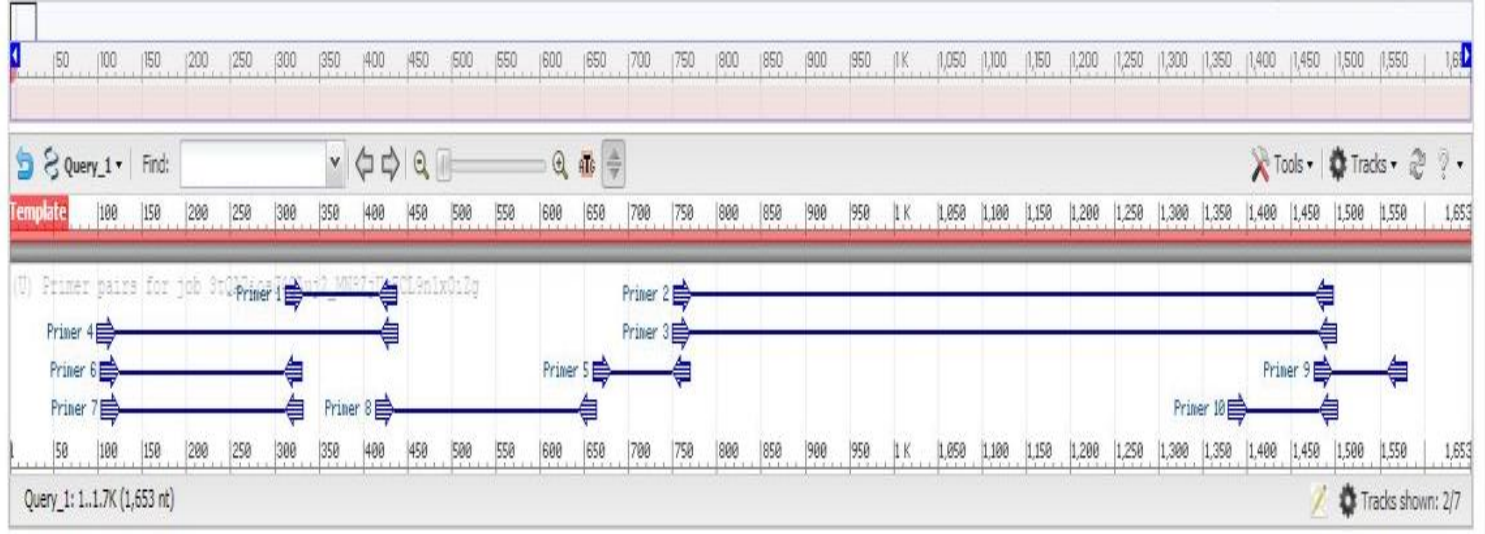

Gambar 2. Ilustrasi daerah yang diamplifikasi oleh setiap pasangan primer. Sepuluh pasang kandidat primer mampu mengenali wilayah gen $l k t B$ dengan panjang produk yang bervariasi. 
Tabel 3. Hasil analisis struktur sekunder menggunakan NetPrimer

\begin{tabular}{|c|c|c|c|c|c|}
\hline Urutan $\left(5^{\prime}->3^{\prime}\right)$ & Self Dimer & Hairpin & $\begin{array}{c}\text { Repeat } \\
\text { (\# of pairs) }\end{array}$ & $\begin{array}{c}\text { Run } \\
\text { (\# of bases) }\end{array}$ & Rating \\
\hline \multicolumn{6}{|l|}{ Pasangan Primer 1} \\
\hline F: CGTAAGGATTTGGGAGCCCT & 2 & 1 & - & 3 & 85 \\
\hline R: GCAGGTAATACGGCACGACA & - & - & - & - & 100 \\
\hline \multicolumn{6}{|l|}{ Pasangan Primer 2} \\
\hline F: GGAGAATTACGATGGGGGCT & 1 & - & - & 5 & 90 \\
\hline R: CTGCCAAGCACTCTCTCCAT & - & - & 3 & - & 100 \\
\hline \multicolumn{6}{|l|}{ Pasangan Primer 3} \\
\hline F: AGGAGAATTACGATGGGGGC & 1 & - & - & 5 & 90 \\
\hline R: TTCCTGCCAAGCACTCTCTC & - & - & 3 & - & 100 \\
\hline \multicolumn{6}{|l|}{ Pasangan Primer 4} \\
\hline F: GAATCGGATGCTGGAATGCT & - & - & - & - & 100 \\
\hline R: GTGCAGGTAATACGGCACGA & 2 & 1 & - & - & 82 \\
\hline \multicolumn{6}{|l|}{ Pasangan Primer 5} \\
\hline F: TCCGGGAACGACCGATTATT & 1 & 1 & - & 3 & 79 \\
\hline R: GCCCCCATCGTAATTCTCCT & 1 & - & - & 5 & 90 \\
\hline \multicolumn{6}{|l|}{ Pasangan Primer 6} \\
\hline F: TCGGATGCTGGAATGCTACTT & - & - & - & - & 100 \\
\hline R: GGGCTCCCAAATCCTTACGA & - & - & - & 3 & 100 \\
\hline \multicolumn{6}{|l|}{ Pasangan Primer 7} \\
\hline F: CGGATGCTGGAATGCTACTTG & - & - & - & - & 100 \\
\hline R: AGGGCTCCCAAATCCTTACG & - & 1 & - & 3 & 99 \\
\hline \multicolumn{6}{|l|}{ Pasangan Primer 8} \\
\hline F: GGTTTGTCGTGCCGTATTACC & 2 & - & - & 3 & 90 \\
\hline R: CGGAACTTTTCCGGAAGCCA & 3 & 2 & - & 4 & 62 \\
\hline \multicolumn{6}{|l|}{ Pasangan Primer 9} \\
\hline F: TCATGGAGAGAGTGCTTGGC & 1 & - & 3 & - & 90 \\
\hline R: GAAATGCCATGCTAACAGCAA & 3 & 2 & - & 3 & 82 \\
\hline \multicolumn{6}{|l|}{ Pasangan Primer 10} \\
\hline F: TTATGGGAGCTGAACACGGAG & 1 & - & - & 3 & 88 \\
\hline R: TTTTCCTGCCAAGCACTCTCT & - & - & 3 & 4 & 100 \\
\hline
\end{tabular}

Keterangan: $\mathrm{F}=$ Forward $; \mathrm{R}=$ Reverse.

Perancangan primer merupakan langkah awal yang menentukan performa amplifikasi dari sebuah proses uji PCR (Praja, 2021). Beberapa hal yang harus diperhatikan dalam mendesain primer yaitu panjang primer, suhu leleh, persentase GC serta kriteria lainnya yaitu jumlah self dimer, hairpin, repeat, and run yang rendah (Pradnyaniti, Wirajana, \& Yowani, 2013; Saraswati et al., 2019).

Pada penelitian ini, seluruh primer yang telah didesain menunjukkan panjang berkisar 20 - 21 basa (Tabel 2). Secara teoritis, primer dengan panjang 18-30 basa merupakan panjang primer yang ideal (Sasmito, Kurniawan, \& Muhimmah, 2014). Primer PCR yang terlalu pendek akan cenderung mengalami mispriming (kesalahan penempelan) dan primer yang terlalu panjang memiliki potensi untuk terjadinya hibridisasi sehingga akan menghambat proses polimerisasi DNA (Anika, Putri, \& Wahyuni, 2019).

Seluruh primer yang telah berhasil didesain pada penelitian ini memiliki persentase GC berkisar 45,45 hingga $55 \%$ (Tabel 2). Persentase GC merupakan faktor penting dalam mendesain primer PCR. Persentase GC adalah jumlah basa guanin dan sitosin dalam suatu primer yang nantinya terkait dengan suhu leleh. Selain itu, persentase GC juga terkait dengan ikatan antar utas DNA. Untuk memutuskan ikatan hidrogen GC, dibutuhkan energi dan suhu yang lebih tinggi dibandingkan dengan AT. Dengan demikian, tingginya kandungan GC akan mempersulit pemutusan rantai utas ganda pada primer dan cetakan. Lebih lanjut, kandungan GC yang rendah pada primer menyebabkan primer tidak mampu menempel dan akan berdampak terhadap penurunan efisiensi PCR. Idealnya, persentase kandungan GC berada pada kisaran 40 - 60 \% (Maitriani, Wirajana, \& Yowani, 2015; Sasmito et al., 2014).

Secara umum, selisih suhu leleh dari seluruh pasangan primer yang didesain tidak melebihi $5{ }^{\circ} \mathrm{C}$ (Tabel 2). Suhu leleh sangat penting dalam menentukan proses denaturasi untai ganda DNA. Primer dengan suhu leleh yang terlalu tinggi (lebih dari $70^{\circ} \mathrm{C}$ ) cenderung mengalami mispriming pada suhu rendah dan primer yang memiliki suhu leleh rendah tidak akan dapat bekerja pada suhu tinggi (Anika et al., 2019). Oleh sebab itu, pasangan primer sebaiknya tidak memiliki selisih suhu leleh yang 
tinggi. Pasangan primer dengan selisih suhu leleh yang lebih dari $5^{\circ} \mathrm{C}$ antara primer forward dan reverse menyebabkan penurunan proses amplifikasi atau bahkan memungkinkan tidak terjadinya proses amplifikasi (Sasmito et al., 2014).

Hasil analisis struktur sekunder menunjukkan hasil yang bervariasi pada setiap pasangan primer (Tabel 3). Primer yang dapat berkomplemen dengan primer lainnya yang sejenis dikenal dengan istilah self-dimer (Sasmito et al., 2014). Keberadaan self-dimer selanjutya akan mengarah pada penurunan efisiensi proses PCR. Run adalah pengulangan urutan satu basa yang sama, misal (AAA) pada primer reverse 9 (Tabel 2 dan 3). Repeat merupakan pengulangan dua basa yang sama, misal (GAGAGA) yang terdapat pada primer forward 9 (Tabel 2 dan 3 ). Keberadaan run dan repeat pada urutan primer dapat menyebabkan mispriming pada proses PCR. Secara umum, run dan repeat yang ditoleransi maksimal berjumlah empat (Sasmitha, Yustiantara, \& Yowani, 2018; Sasmito et al., 2014). Faktor lain yang harus diperhatikan adalah hairpin. Hairpin merupakan kondisi dimana ujung-ujung dari primer saling berkomplemen. Keberadaan interaksi hairpin tidak dapat ditoleransi dalam proses desain primer (Sasmitha et al., 2018).

Secara umum, pada penelitian ini diperoleh beberapa pasangan primer dengan panjang produk yang bervariasi (Tabel 2 dan Gambar 2). Primer dengan produk yang terpendek dan terpanjang secara berturut-turut dihasilkan oleh pasangan primer 9 dan 3 dengan panjang produk 105 dan 751 bp atau sekitar 7 dan $44 \%$ dari total gen $l k t B$. Secara spesifik, hasil analisis dari primer forward 6 (5'-TCGGATGCTGGAATGCTACT T-3') dan primer reverse 6 (5'-GGGCTCCCAAA TCCTTACGA-3') menunjukkan ukuran amplikon sebesar 228 bp yang mengamplifikasi daerah 103-330 dari gen lktB F. necrophorum (Tabel 2 dan Gambar 3). Meskipun pasangan primer 6 hanya mengamplifikasi daerah dengan ukuran sekitar $14 \%$ dari total ukuran $l k t B$ (Gambar 3), namun hasil analisis lebih lanjut menunjukkan bahwa pasangan primer 6 merupakan pasangan primer terbaik yang dapat mengamplifikasi gen target karena memenuhi kriteria ideal. Pasangan primer ini memiliki selisih Tm yang sangat kecil yaitu $0,05{ }^{\circ} \mathrm{C}$, persentase GC sebesar 47,62 dan 55,00 \%, serta tidak memiliki self dimer, hairpin, dan repeat. Primer ini teridentifikasi tidak memiliki run pada primer forward tetapi memiliki tiga run pada primer reverse. Lebih lanjut, hasil analisis menggunakan NetPrimer menunjukkan bahwa pasangan primer ini memiliki nilai atau rating tertinggi dengan nilai 100 dibandingkan dengan primer lainnya (Tabel 2 dan 3).

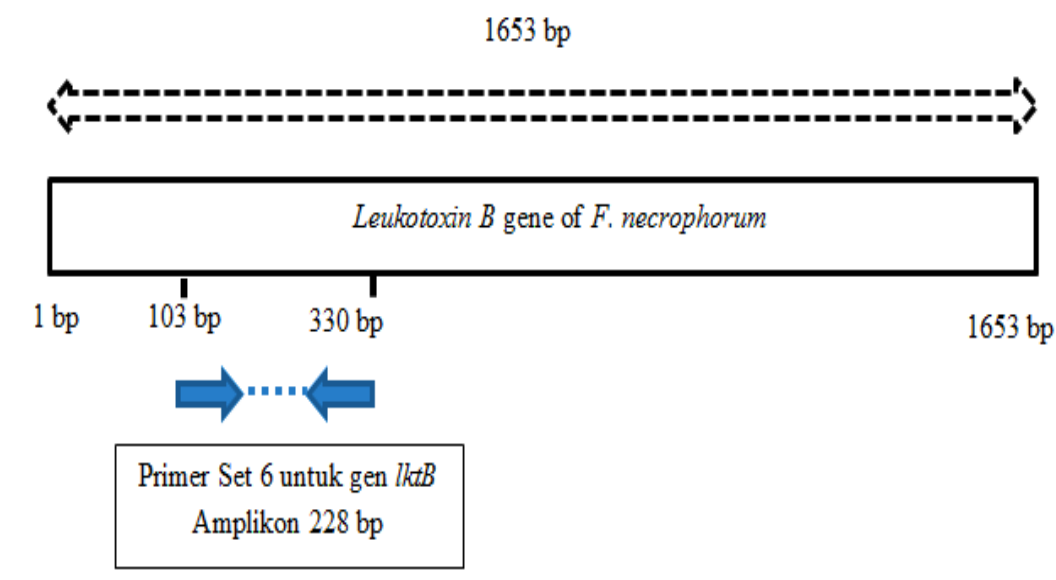

Gambar 3. Posisi relatif dari pasangan primer 6. Pasangan primer ini mengamplifikasi daerah 103 330 dari gen $l k t B$ F. necrophorum (Nomor akses GenBank NCBI: AF312861.3:685-2337).

Uji terkait similaritas dari pasangan primer 6 dilakukan menggunakan Nucleotide BLAST yang tersedia di dalam situs GenBank NCBI. Hasil analisis pada primer forward 6 menunjukkan bahwa primer ini memiliki kemiripan sebesar $100 \%$ dengan gen $l k t B$ yang terdapat pada $F$. necrophorum (Nomor akses CP033837.1, CP034842.1, dan AF312861.3). Lebih lanjut, primer forward 6 juga memiliki kesamaan yang lebih rendah berkisar $85 \%$ dengan berbagai gen yang terdapat pada organisme lain (Gambar 4 dan Tabel 4). 


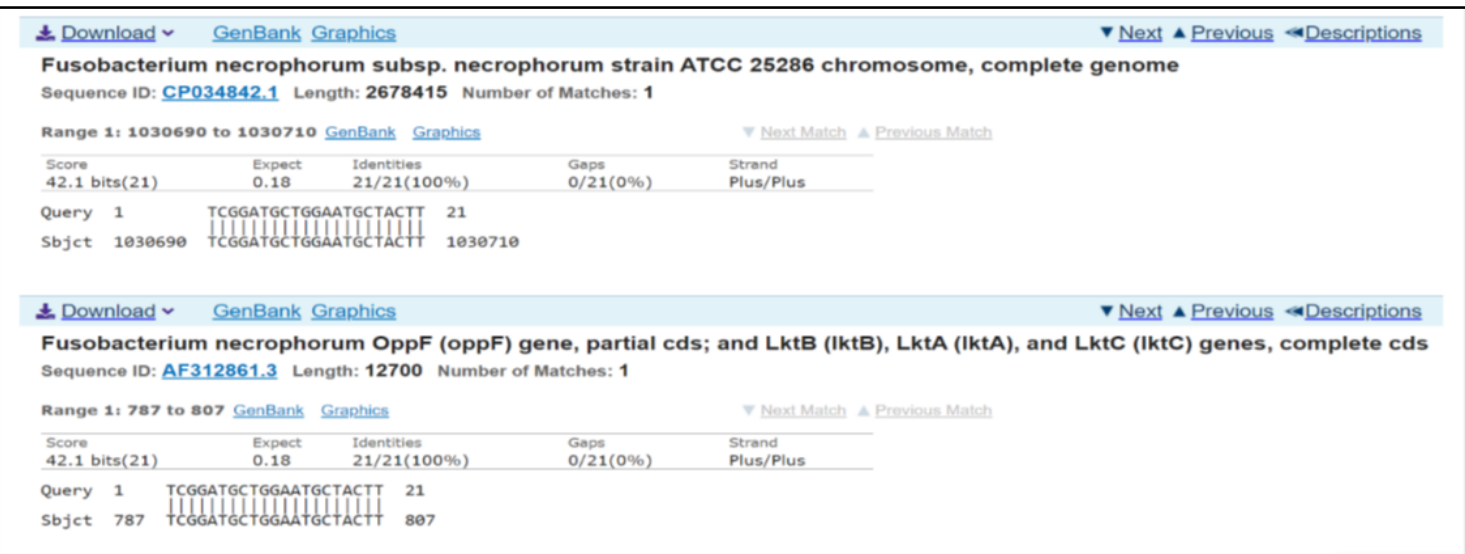

Gambar 4. Representasi hasil Nucleotide BLAST dari primer forward 6. Urutan nukleotida primer forward 6 memiliki kemiripan sebesar $100 \%$ dengan F. necrophorum

Tabel 4. Hasil Nucleotide BLAST pada primer forward 6

\begin{tabular}{lcc}
\hline Deskripsi & Kesamaan & Nomor Akses \\
\hline Fusobacterium necrophorum & $100 \%$ & $\underline{\text { CP033837.1 }}$ \\
Fusobacterium necrophorum subsp. necrophorum & $100 \%$ & $\underline{\text { CP034842.1 }}$ \\
Fusobacterium necrophorum & $100 \%$ & $\underline{\text { AF312861.3 }}$ \\
Quercus lobata & $85 \%$ & $\underline{\text { LR531087424.1 }}$ \\
Sparus aurata & $85 \%$ & $\underline{\text { CP032587.1 }}$ \\
Lateolabrax maculatus & $85 \%$ & $\underline{\text { FR997738.1 }}$ \\
Ochropleura plecta & $85 \%$ & $\underline{\text { LR990644.1 }}$ \\
Xestia xanthographa & $85 \%$ & $\underline{\text { LR899613.1 }}$ \\
Darwinula stevensoni & $85 \%$ & $\underline{\text { XM 032703373.1 }}$ \\
Chiroxiphia lanceolata & $85 \%$ &
\end{tabular}

Keterangan: Data yang ditampilkan merupakan 10 organisme dengan gen yang memiliki kemiripan tertinggi dengan primer forward 6. Data dianalisis pada tanggal 15 Mei 2021.

Uji similaritas pada primer reverse 6 juga menunjukkan hasil kemiripan sebesar $100 \%$ dengan gen $l k t B$ yang dimiliki oleh $F$. necrophorum dengan nomor akses CP033837.1, CP034842.1, dan AF312861.3. Kesamaan yang lebih rendah diperoleh pada berbagai gen dari organisme lain dengan nilai kemiripan berkisar $90-95 \%$ (Gambar 5 dan Tabel 5). Berdasarkan uji similaritas ini, dapat diperkirakan bahwa pasangan primer 6 merupakan primer yang sangat spesifik untuk mengamplifikasi gen $l k t B F$. necrophorum karena pasangan primer 6 baik forward dan reverse hanya memiliki kemiripan $100 \%$ dengan $l k t B F$. necrophorum.

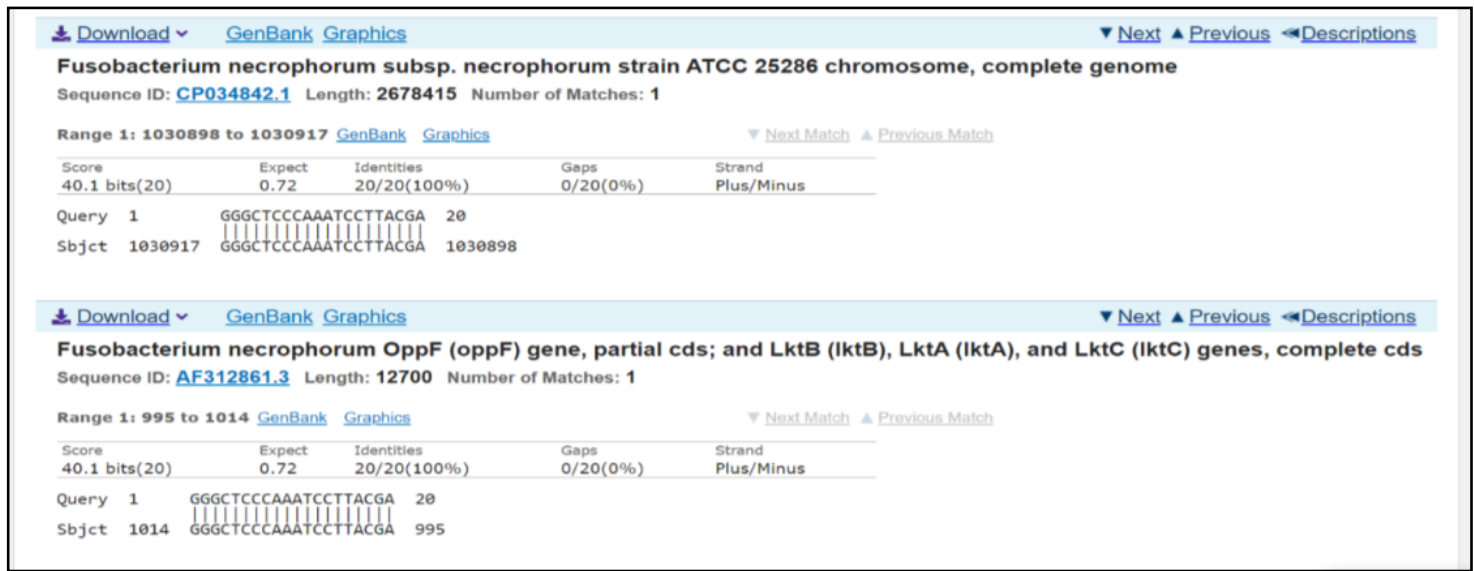

Gambar 5. Representasi hasil Nucleotide BLAST dari primer reverse 6. Urutan nukleotida primer reverse 6 memiliki kemiripan sebesar $100 \%$ dengan $F$. necrophorum. 
Tabel 5. Hasil Nucleotide BLAST pada primer reverse 6

\begin{tabular}{lcc}
\hline Deskripsi & Kesamaan & Nomor Akses \\
\hline Fusobacterium necrophorum & $100 \%$ & $\underline{\text { CP033837.1 }}$ \\
Fusobacterium necrophorum subsp. necrophorum & $100 \%$ & $\underline{\text { CP034842.1 }}$ \\
Fusobacterium necrophorum & $100 \%$ & $\underline{\text { AF312861.3 }}$ \\
Apteryx mantelli mantelli & $95 \%$ & $\underline{\text { LK064839.1 }}$ \\
Exophiala dermatitidis NIH/UT8656 & $95 \%$ & $\underline{\text { X } 009154451.1}$ \\
Bombus hortorum & $95 \%$ & $\underline{\text { HG995201.1 }}$ \\
Maniola hyperantus & $90 \%$ & $\underline{\text { LR761660.1 }}$ \\
Bradyrhizobium japonicum & $90 \%$ & $\underline{\text { CP017637.1 }}$ \\
Acetobacter ascendens & $90 \%$ & $\underline{\text { CP015164.1 }}$ \\
Autographa pulchrina & $90 \%$ & $\underline{\text { FR997766.1 }}$
\end{tabular}

Keterangan: Data yang ditampilkan merupakan 10 organisme dengan gen yang memiliki kemiripan tertinggi dengan primer reverse 6. Data dianalisis pada tanggal 15 Mei 2021.

Primer yang dirancang menggunakan studi in silico idealnya harus dioptimasi di tingkat laboratorium untuk memperoleh kondisi yang optimal. Optimasi yang harus dilakukan meliputi annealing temperature $(\mathrm{Ta})$ dan konsentrasi primer serta batas minimum yang mampu dideteksi. Berbagai optimasi lab tersebut dilakukan untuk mencapai hasil PCR yang optimal (Saraswati et al., 2019).

\section{Kesimpulan}

Pasangan primer yang spesifik untuk amplifikasi gen $l k t B F$. necrophorum telah berhasil didesain. Pasangan primer 6 merupakan pasangan primer yang terbaik berdasarkan analisis in silico. Primer ini telah berhasil memenuhi persyaratan utama sebagai primer yang baik dalam hal panjang primer, suhu leleh, dan persentase GC dengan amplikon $228 \mathrm{bp}$. Sebagai tambahan, optimasi laboratorium perlu dilakukan untuk memperoleh kondisi optimal dari pasangan primer ini dan memastikan pasangan primer ini dapat mengamplifikasi gen lktB dengan baik.

\section{Daftar Pustaka}

Anika, M., Putri, D. H., \& Wahyuni. (2019). Primer design for identification of betacarotene encoding genes in cassava. Bio Sains, 4(1), 39-47.

Clifton, R., Giebel, K., Liu, N. L. B. H., Purdy, K. J., \& Green, L. E. (2019). Sites of persistence of Fusobacterium necrophorum and Dichelobacter nodosus: a paradigm shift in understanding the epidemiology of footrot in sheep. Scientific Reports, 9(14429), 1-11. https://doi.org/ 10.1038/s41598019-50822-9

Kadri, K. (2020). Polymerase Chain Reaction (PCR): Principle and Applications. In M. L. Nagpal, O.-M. Boldura, C. Balta, \& S.
Enany (Eds.), Synthetic Biology-New Interdisciplinary Science (pp. 147-164). London: IntechOpen. https://doi.org/ 10.5772/intechopen.88813

Maitriani, L. K. B., Wirajana, I. N., \& Yowani, S. C. (2015). Desain primer untuk amplifikasi fragmen gen inhA isolat 134 multidrug resistance tuberculosis (MDRTB) dengan metode polymerase chain reaction. Cakra Kimia (Indonesian E-Journal of Applied Chemistry), 3(2), 89-96.

Pillai, D. K., Amachawadi, R. G., Baca, G., Narayanan, S. K., \& Nagaraja, T. G. (2021). Leukotoxin production by Fusobacterium necrophorum strains in relation to severity of liver abscesses in cattle. Anaerobe, 69(102344). https://doi. org/10.1016/j.anaerobe.2021.102344

Pradnyaniti, D. G., Wirajana, I. N., \& Yowani, S. C. (2013). Desain primer secara in silico untuk amplifikasi fragmen gen rpoB Mycobacterium tuberculosis dengan polymerase chain reaction (PCR). Jurnal Farmasi Udayana, 124-129.

Praja, R. K. (2021). In silico oligonucleotide primer design for Campylobacter jejuni cytolethal distending toxin $\mathrm{B}$ gene amplification. Oceana Biomedicina Journal, 4(1), 53-65. https://doi.org/10.30649/ OBJ.V4I1.88

Saleh, W. M. M., Naji, H. A., Lafta, M. H., AlHusseiny, S. H., Abood, F. A., \& Yassir, S. K. (2019). Clinical and bacteriological diagnosis of foot-rot in beef bulls in Basra. Biomedical: Journal of Science \& Technical Research, 13(5), 1-5. https://doi.org/10. 26717/BJSTR.2019.13.002472

Saraswati, H., Seprianto, \& Wahyuni, F. D. (2019). Desain primer secara in silico untuk amplifikasi gen cryIII dari Bacillus 
thuringiensis isolat lokal. Indonesian Journal of Biotechnology and Biodiversity, 3(1), 33-38.

Sasmitha, L. V., Yustiantara, P. S., \& Yowani, S. C. (2018). Desain DNA primer secara in silico sebagai pendeteksi mutasi gen gyrA Mycrobacterium tuberculosis untuk metode polymerase chain reaction. Cakra Kimia (Indonesian E-Journal of Applied Chemistry), 8(1), 63-69.

Sasmito, D. E. K., Kurniawan, R., \& Muhimmah, I. (2014). Karakteristik primer pada polymerase chain reaction (PCR) untuk sekuensing DNA: mini review. Seminar Nasional Informatika Medis (SNIMed) V, (5), 93-102. Magister Teknik Informatika, Fakultas Teknologi Industri, Universitas Islam Indonesia.

Sint, D., Raso, L., \& Traugott, M. (2012). Advances in multiplex PCR: balancing primer efficiencies and improving detection success. Methods in Ecology and Evolution, 3(5), 898-905. https://doi.org/10.1111/ j.2041-210X.2012.00215.x

Tadepalli, S., Stewart, G. C., Nagaraja, T. G., \& Narayanan, S. K. (2008). Leukotoxin operon and differential expressions of the leukotoxin gene in bovine Fusobacterium necrophorum subspecies. Anaerobe, 14(1), 13-18. https: //doi.org /10.1016/ j. anaerobe.2007.09.001

Umana, A., Sanders, B. E., Yoo, C. C., Casasanta, M. A., Udayasuryan, B., Verbridge, S. S., \& Slade, D. J. (2019). Reevaluating the Fusobacterium virulence factor landscape. BioRxiv, 1-35. https:// doi.org/10.1101/534297

Van Metre, D. C. (2017). Pathogenesis and treatment of bovine foot rot. Veterinary Clinics of North America: Food Animal Practice, 33(2), 183-194. https://doi.org/ 10.1016/j.cvfa.2017.02.003

Veloso, V. A., \& Drouillard, J. S. (2020). On the potential role of dietary lysine as a contributing factor in development of liver abscesses in cattle. Frontiers in Veterinary Science, 7, 1-4. https://doi.org/10.3389/ fvets.2020.576647 